\title{
RISK FACTORS OF FILARIASIS IN CHILDREN, BUKITTINGGI, WEST SUMATERA
}

\author{
Masrizal, Aulia Rahmi Fitri Yani, Randa Ilham \\ Department of Epidemiology and Biostatistics, Faculty of Public Health, \\ Universitas Andalas
}

\begin{abstract}
Background: Lymphatic filariasis remains a major global public health problem and is 1 of the World Health Organization's 6 diseases targeted for global eradication. Filariasis is a chronic infectious disease caused by filarial worm infection and can lead to disability in the affected. This study aimed to determine the risk factors of lymphatic filariasis in children in Bukittinggi, West Sumatera.

Subjects and Method: This was a case control study conducted in Bukitinggi, West Sumatera. A sample of 80 children was selected for this study, consisiting of 40 filariasis cases and 40 controls. The dependent variable was filariasis infection. The independent variables were maternal education, maternal knowledge, use of mosquito net, use of mosquito repellent, hanging clothes, use of wire net, presence of house ceiling, animal reservoir. Filariasis data was obtained from the medical record. The other data were collected by questionnaire. The data were analyzed by a multiple logistic regression.

Results: The risk of filariasis infection in children increased with low maternal education $(\mathrm{OR}=1.20 ; 95 \% \mathrm{CI}=0.36$ to 3.93$)$, poor maternal knowledge $(\mathrm{OR}=2.00$; $95 \% \mathrm{CI}=0.89$ to 4.45$)$, non-user of mosquito net $(\mathrm{OR}=1.14 ; 95 \% \mathrm{CI}=0.41$ to 3.15$)$, non-user of mosquito repellent $(\mathrm{OR}=1.25 ; 95 \% \mathrm{CI}=0.49$ to 3.16$)$, hanging clothe habit $(\mathrm{OR}=7.00,95 \% \mathrm{CI}=1.59$ to 30.30$)$, non-user of wire net $(\mathrm{OR}=1.37 ; 95 \% \mathrm{CI}=$ 0.55 to 3.41 ), non-user of house ceiling ( $\mathrm{OR}=4.00 ; 95 \% \mathrm{CI}=1.12$ to 14.17 ), presence of animal reservoir $(\mathrm{OR}=1.25 ; 95 \% \mathrm{CI}=0.58$ to 2.67$)$.

Conclusion: Low-quality housing is associated with an increased risk of filariasis infection. Poor preventive practices of mosquito bite is also associated with an increased risk of filariasis infection.
\end{abstract}

Keywords: filariasis, infection, risk factor.

\section{Correspondence:}

Masrizal. Department of Epidemiology and Biostatistics, Faculty of Public Health, Universitas Andalas, Padang, West Sumatera.

Email: masrizal_khaidir@yahoo.com. Mobile: 08126733228.

The 4th International Conference on Public Health Best Western Premier Hotel, Solo, Indonesia, August 29-30, 2018 | 82 https://doi.org/10.26911/theicph.2018.01.43 